\title{
Geologia do Grupo Paranoá na porção externa da Faixa Brasília
}

\author{
The Paranoá Group geology at the external portion of the Brasília Belt \\ José Eloi Guimarães Campos ${ }^{1 *}$, Marcel Auguste Dardenne ${ }^{1}$, Flavio Henrique \\ Freitas-Silva ${ }^{2}$, Marco Antônio Caçador Martins-Ferreira ${ }^{1}$
}

\begin{abstract}
RESUMO: O Grupo Paranoá corresponde a uma sucessáo psamo-pelito-carbonatada depositada em condiçôes plataformais. A estratigrafia desse importante conjunto litoestratigráfico da Faixa de Dobramentos Brasília foi inicialmente proposta sob a designação de letras-código que inclui 11 unidades com o seguinte empilhamento estratigráfico: $S M, R_{1}$, $\mathrm{Q}_{1}, \mathrm{R}_{2}, \mathrm{Q}_{2}, \mathrm{~S}, \mathrm{~A}, \mathrm{R}_{3}, \mathrm{Q}_{3}, \mathrm{R}_{4}$ e PC. O presente trabalho formaliza tais unidades e atribui a seguinte denominação às formaçóes, da base para $\mathrm{o}$ topo: Ribeirão São Miguel, Córrego Cordovil, Serra da Boa Vista, Serra Almécegas, Serra do Paraná, Ribeirão Piçarrão, Ribeirão do Torto, Serra da Meia Noite, Ribeirão Contagem, Córrego do Sansão e Córrego do Barreiro. A deposição do Grupo Paranoá é interpretada como ocorrida no Mesoproterozoico (1.542 a $1.042 \mathrm{Ma}$ ). Essa idade é corroborada por sua posição estratigráfica (ocorre sobre sedimentos da fase pós-rifte do Grupo Araí e sob pelitos e carbonatos do Grupo Bambuí), pela presença de estromatólitos cônicos (conophyton) e por dados isotópicos. A sedimentação foi controlada por ciclos transgressivos-regressivos, incluindo processos trativos, suspensivos, fluxos de detritos, marés, ondas, tempestades e controle da paleogeografia de fundo. O conjunto foi afetado por metamorfismo de baixo grau e a deformação resultou na formação de monoclinais, diferentes estilos de dobras (chevrons, em caixa e cilíndricas) e interferência de dobramentos formando domos e bacias estruturais. A deformação regional do Grupo Paranoá é controlada principalmente pelos sistemas de cavalgamentos Paranã e Rio Maranhão, além da faixa de transcorrência Ribeirão São Miguel.
\end{abstract}

PALAVRAS-CHAVE: Grupo Paranoá; ciclos transgressivo-regressivos; Mesoproterozoico.

\begin{abstract}
The Paranoa Group represents a psamo-pelitic-carbonated succession deposited in shelf conditions. The stratigraphy of this important lithostratigraphic sequence of the Brasilia Fold Belt was originally proposed by letter-code designation that includes 11 units with the following stratigraphic stacking: $S M, R_{1}, Q_{1}, R_{2}, Q_{2}, S, A$, $R_{3}, Q_{3}, R_{4}$ and $P C$. The present paper formalizes these units and proposes the following denomination to the formations, named from base to top: Ribeirão São Miguel, Córrego Cordovil, Serra da Boa Vista, Serra Almécegas, Serra do Paranã, Ribeirão Piçarrão, Ribeirão do Torto, Serra da Meia Noite, Ribeirão Contagem, Córrego do Sansão and Córrego do Barreiro. The deposition of the Paranoa Group is considered to have been processed in the Mesoproterozoic (1,542 to 1,042 Ma). This age interpretation is supported by the stratigraphic position (as it occurs over the post-rift phase sediments of the Arai Group and under slates and carbonates of the Bambui Group), by the presence of conical stromatolite (conophyton) and by isotopic data. The sedimentation was controlled by transgressive-regressive cycles, including grading and traction processes, debris flows, tides, waves, storms and basin bottom paleogeography. The sediments were affected by low-grade metamorphism and the deformation resulted in the formation of monoclines, different styles of folds (chevrons, in box and cylindrical ones) and folding interference resulting in domes and structural basins. The regional deformation of the Paranoa Group is mainly controlled by the Parana and Rio Maranhão thrust systems and by the Ribeirão São Miguel shear belt.
\end{abstract}

KEYWORDS: Paranoá Group; transgressive-regressive cycles; Mesoproterozoic.

11nstituto de Geociências, Universidade de Brasília - UnB, Brasília (DF), Brasil.E-mails: eloi@unb.br; marcoc@unb.br ${ }^{2}$ Companhia Vale, Santa Luzia (MG), Brasil.E-mail:flavio.freitas@vale.com

*Autor correspondente

Manuscrito ID 29931. Recebido em: 03/03/2013. Aprovado em: 20/08/2013. 


\section{INTRODUÇÃO}

O Grupo Paranoá corresponde a uma sequência psamo-pelito-carbonatada que está exposta desde o Distrito Federal até o sul do Estado de Tocantins. A denominação Grupo Paranoá é uma modificação da proposta original de Andrade Ramos (1956) que utilizou o termo "Paranauá" para se referir aos quartzitos e filitos que ocorrem na região do Distrito Federal, inicialmente posicionados no Grupo Bambuí e posteriormente redefinidos como pertencentes ao Grupo Canastra (Andrade Ramos 1958). Ignorando a proposta original de Costa \& Branco (1961), Braun \& Baptista (1978) incorporaram essa unidade à base do Grupo Bambuí. Dardenne (1978) retira a Formação Paranoá da base do Grupo Bambuí elevando seu status para a categoria de Grupo Paranoá. Posteriormente, outros autores desenvolveram estudos sobre essa unidade litoestratigráfica, incluindo Baeta et al. (1978), Laranjeira (1992) e Guimarães (1997).

O Grupo Paranoá representa uma sequência de preenchimento de bacia de primeira ordem que se estende para o interior do Cráton e que é recoberta por unidades do Grupo Bambuí (Braun et al. 1993; Teixeira et al. 1993, Martins-Neto 2009).

Faria (1995) detalhou a estratigrafia do Grupo Paranoá na área-tipo de Alto Paraíso de Goiás e São João D’Aliança; entretanto, não formalizou as unidades em nível de formaçôes. Condé et al. (1994) estudaram o Grupo Paranoá na Serra do Paranã na região de São Gabriel, Goiás. FreitasSilva \& Campos $(1995,1998)$ detalharam a sucessão dos metassedimentos do Grupo Paranoá no Distrito Federal.

O presente estudo inclui toda a extensão de ocorrências das rochas do Grupo Paranoá entre o Distrito Federal e o Parque Nacional da Chapada dos Veadeiros. Entretanto, essa unidade ocorre em outras áreas da Faixa de Dobramentos Brasília, como em Cristalina, Caldas Novas e Formosa, no estado de Goiás, e na regiāo de Unaí, no estado de Minas Gerais (Fig. 1).

Os objetivos deste trabalho são formalizar a estratigrafia do Grupo Paranoá na sua área-tipo, atualizar as interpretaçôes dos sistemas deposicionais e tecer consideraçôes sobre a evolução sedimentar dessa importante unidade litoestratigráfica da Faixa de Dobramentos Brasília.

\section{CONTEXTO GEOLÓGICO REGIONAL}

Em sua extensa área de ocorrência, no Brasil Central, o Grupo Paranoá apresenta-se em duas situaçôes distintas, nas zonas externa e interna da Faixa Brasília, evidenciando variaçóes laterais de fácies de leste para oeste. $\mathrm{Na}$ zona externa, compreendendo a região do Distrito Federal até Alto Paraíso de Goiás, o Grupo Paranoá caracteriza-se pelo seu caráter anquimetamórfico até a fácies xisto verde baixo, englobando como litotipos característicos conglomerados, ardósias, metarritmitos, metacalcáreos e metadolomitos onde, em geral, as feiçôes sedimentares primárias estão preservadas. Na zona interna da Faixa Brasília, o grupo apresenta maior grau metamórfico e maior grau de deformação, caracterizando-se pela presença de filitos carbonosos, quartzitos, metacarbonatos (por exemplo, Niquelândia ou Minaçu - GO, Fuck et al. 1988). A correlação entre as unidades presentes nas zonas externa e interna da faixa somente foi possível devido à presença de um conglomerado basal (Conglomerado São Miguel) e sequências carbonáticas contendo os mesmos estromatólitos dos gêneros Kussiela, Colonnella, Conophyton e Baicalia.

Em função de variações ambientais e paleogeográficas, a estratigrafia do Grupo Paranoá apresenta variaçóes laterais e verticais quando comparada às várias localidades de exposição da sequência. Contudo, Faria (1995) propóe uma estratigrafia integrada que pode ser correlacionada regionalmente na porção mais externa da Faixa Brasília. As unidades foram denominadas informalmente por letras-código da base para o topo: $\mathrm{SM}, \mathrm{R}_{1}, \mathrm{Q}_{1}, \mathrm{R}_{2}, \mathrm{Q}_{2}, \mathrm{~S}, \mathrm{~A}$, $\mathrm{R}_{3}, \mathrm{Q}_{3}, \mathrm{R}_{4}$ e $\mathrm{PC}$. As principais feiçóes de cada litofácies são descritas a seguir:

- Unidade SM (informalmente denominada de conglomerado São Miguel): representada por um paraconglomerado com seixos, calhaus e blocos subangulosos de metassiltitos, quartzo, quartzitos e mármores finos cinzas flutuantes em uma matriz síltico-argilo-carbonatada. Esta unidade ocorre em áreas distantes; entretanto, não é contínua e apresenta espessura máxima de $60 \mathrm{~m}$.

- Unidade $\mathrm{R}_{1}$ : apresenta contato concordante com o conglomerado São Miguel e é constituída por uma sucessão de horizontes margosos e metassiltitos argilosos na base, passando para um metarritmito com delgadas intercalaçôes de quartzitos finos a médios, geralmente feldspáticos. Gretas de contração e pseudomorfos de cubo de sal são frequentemente observados próximo à base do pacote. Nas áreas-tipo, alcança $70 \mathrm{~m}$ de espessura.

- Unidade $\mathrm{Q}_{1}$ : é representada por quartzitos finos a médios, brancos, bem estratificados em bancos de 30 a $40 \mathrm{~cm}$ e com raras intercalaçôes de horizontes síltico-argilosos no topo e frequentes estratos cruzados tabulares. Apresenta até $80 \mathrm{~m}$ de espessura.

- Unidade $\mathrm{R}_{2}$ : apresenta passagem abrupta a partir do quartzito anterior e uma espessura de até $150 \mathrm{~m}$, sendo caracterizada por bancos centimétricos de quartzitos finos rosados, intercalados com metassiltitos e níveis milimétricos de lamitos de coloração esbranquiçada. 
São comuns as laminaçóes cruzadas truncadas por ondas, marcas onduladas assimétricas nos bancos de quartzitos, quick sand e estruturas de fluidização.

- Unidade $\mathrm{Q}_{2}$ : composta por camadas decimétricas a métricas de quartzitos amarelo-ocres de granulação média a grossa. Em direção ao topo da sucessão, são comuns leitos e canais conglomeráticos finos feldspáticos, com grânulos e seixos subangulosos a arredondados. As estratificaçôes cruzadas tabulares reviradas e do tipo espinha de peixe são comuns. Sua espessura pode alcançar $150 \mathrm{~m}$.
Unidade S: é o pacote que apresenta maior variabilidade, podendo alcançar espessuras superiores a $500 \mathrm{~m}$. É subdivido em cinco litofácies, sendo um conjunto de metassiltitos esverdeados homogêneos que podem conter intercalaçóes arenosas compondo metarritmitos ou lentes de calcários e dolomitos (estas últimas bastante raras).

- Unidade A: apresenta contato transicional a partir da unidade anterior, sendo constituída por ardósias homogêneas de cor cinza esverdeada, que passam a tons vermelhos característicos com a alteração intempérica. Neste conjunto, são observadas duas foliaçóes

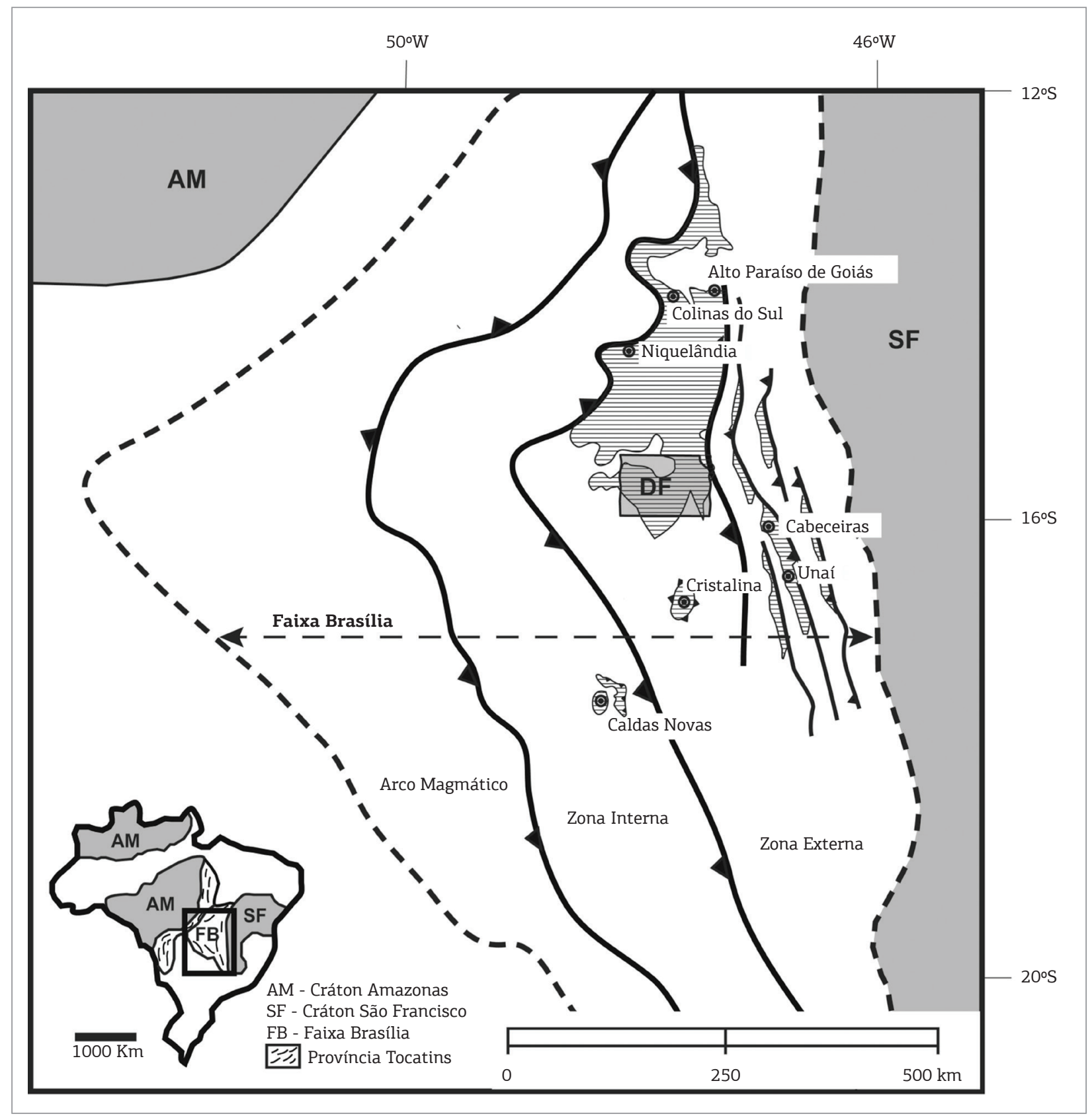

Figura 1. Distribuição do Grupo Paranoá nas porções interna e externa da Faixa de Dobramentos Brasília. 
penetrativas que representam clivagens ardosianas. Sua espessura é de difícil estimativa em virtude do intenso dobramento, sendo considerada da ordem de $70 \mathrm{~m}$.

- Unidade $\mathrm{R}_{3}$ : corresponde a um metarritmito arenoso, caracterizado por intercalaçóes de bancos decimétricos a métricos de quartzitos e materiais pelíticos (compostos por metassiltitos e ardósias). Localmente, são observados pacotes de até $10 \mathrm{~m}$ de espessura que destacam do conjunto rítmico. A espessura total deste conjunto pode alcançar $90 \mathrm{~m}$.

- Unidade $\mathrm{Q}_{3}$ : composta por quartzitos brancos, finos, bastante silicificados, ricos em estratificaçôes cruzadas tabulares, acanaladas e do tipo espinha de peixe, além de marcas onduladas assimétricas. A máxima espessura de 100 m é estimada na região do Distrito Federal.

- Unidade $\mathrm{R}_{4}$ : metarritmito argiloso, composto por intercalaçóes de materiais sílticos e argilosos, além de delgados estratos de quartzitos finos rosados a avermelhados. Os níveis arenosos apresentam estruturas do tipo laminaçôes cruzadas, laminaçóes truncadas por ondas e hummockys. Esta unidade apresenta espessuras variando de 100 a $150 \mathrm{~m}$.

- Unidade PC: dominantemente pelítica, com ardósias cinzas e metassiltitos argilosos associados com lentes de mármores finos que podem conter estruturas algais do tipo estromatólitos colunares e cônicos. São comuns os níveis decimétricos a métricos, lenticulares ou não, de quartzitos médios, grossos e até conglomeráticos, apresentando tonalidades escuras. Sua espessura varia de 120 a $150 \mathrm{~m}$.

A idade do Grupo Paranoá foi estabelecida em função das relaçóes estratigráficas com os grupos Araí e Bambuí (respectivamente correspondentes à sua base e topo), por correlaçóes regionais e principalmente em função das estruturas estromatolíticas, presentes nas rochas carbonáticas. Os estromatólitos (colunares e conophyton) e os dados isotópicos disponíveis indicam idade para a sedimentaçáo entre 1.000 e $1.300 \mathrm{Ma}$, o que posiciona a unidade no Mesoproterozoico (Dardenne et al. 1972, Cloud \& Dardenne 1973, Dardenne 1979, Matteini et al. 2012).

Informações isotópicas $\mathrm{Sm} / \mathrm{Nd}$ (Santos et al. 2000, 2004, Pimentel et al. 2001, além de dados inéditos) indicam que as idades modelo para as diferentes unidades do Grupo Paranoá variam entre 1,81 e 2,27 Ga, o que mostra que as fontes dos detritos têm idade principalmente paleoproterozoica.

Matteini et al. (2012), a partir de estudos isotópicos $\mathrm{U}-\mathrm{Pb}$ e Hf sobre zircóes detríticos, concluem sobre a idade mínima de deposição do Grupo Paranoá de $1.042 \mathrm{Ma}$ baseado em sobrecrescimento diagenético de xenotima em zircâo detrítico e idade máxima de $1.542 \mathrm{Ma}$ em função da população de zircôes mais jovens. Além desse intervalo de idade, os autores apresentam ampla discussão sobre a geologia da área fonte e proveniência dos sedimentos terrígenos da bacia Paranoá.

Os sistemas deposicionais, atribuídos ao Grupo Paranoá, correspondem a condiçóes marinhas plataformais epicontinentais, sendo a variação das proporções de materiais arenosos e argilosos relacionada a variaçôes da profundidade da lâmina d'água, em função de ciclos transgressivos-regressivos.

\section{ESTRATIGRAFIA E DESCRIÇÃO DE LITOFÁCIES}

A proposta de Faria (1995) para o empilhamento estratigráfico do Grupo Paranoá é considerada completa e adequada, de forma que o presente trabalho definirá as áreas-tipos e holoestratótipos para cada unidade que deverá ser definida como formação, além de detalhar as condiçôes de deposição de cada formação. A Fig. 2 apresenta a estratigrafia com as respectivas denominaçóes das formaçóes e principais litofácies que as integram. A Fig. 3 apresenta a localização das áreas-tipo de cada formação proposta. Na Tab. 1, é apresentada a correlação das unidades informais com as formaçôes propostas, bem como suas áreas-tipo de ocorrência.

\section{Formação Ribeirão São Miguel}

A área-tipo e o holoestratótipo são representados pela localidade denominada Vale da Lua, ao sul do Parque Nacional da Chapada dos Veadeiros. Além do trabalho de Faria (1995), Campos et al. (2005) apresentam detalhamento petrográfico e análise sobre o ambiente deposicional desta unidade.

A Formação Ribeirão São Miguel (conglomerado São Miguel - Dyer 1970) é representada essencialmente por conglomerados matriz-suportados, com matriz arenosa e cimentos de carbonatos. Os clastos são de quartzitos finos ou médios, metassiltitos, mármores finos, apresentando diâmetros variáveis desde milimétricos até decimétricos; blocos com até $1 \mathrm{~m}$ são observados localmente. $\mathrm{Na}$ fácies mais comum, predominam clastos de 1 a $4 \mathrm{~cm}$, com formas variadas, onde é possível verificar fragmentos desde subarredondados até muito angulosos.

Campos et al. (2005) dividiram esta formação nas seguintes fácies: Rudito Médio a Grosso Maciço, Rudito Fino, Brecha Maciça e pelítica. De forma geral, os ruditos são maciços, mas localmente fácies com acamamento difuso ou laminação podem ser observadas. 


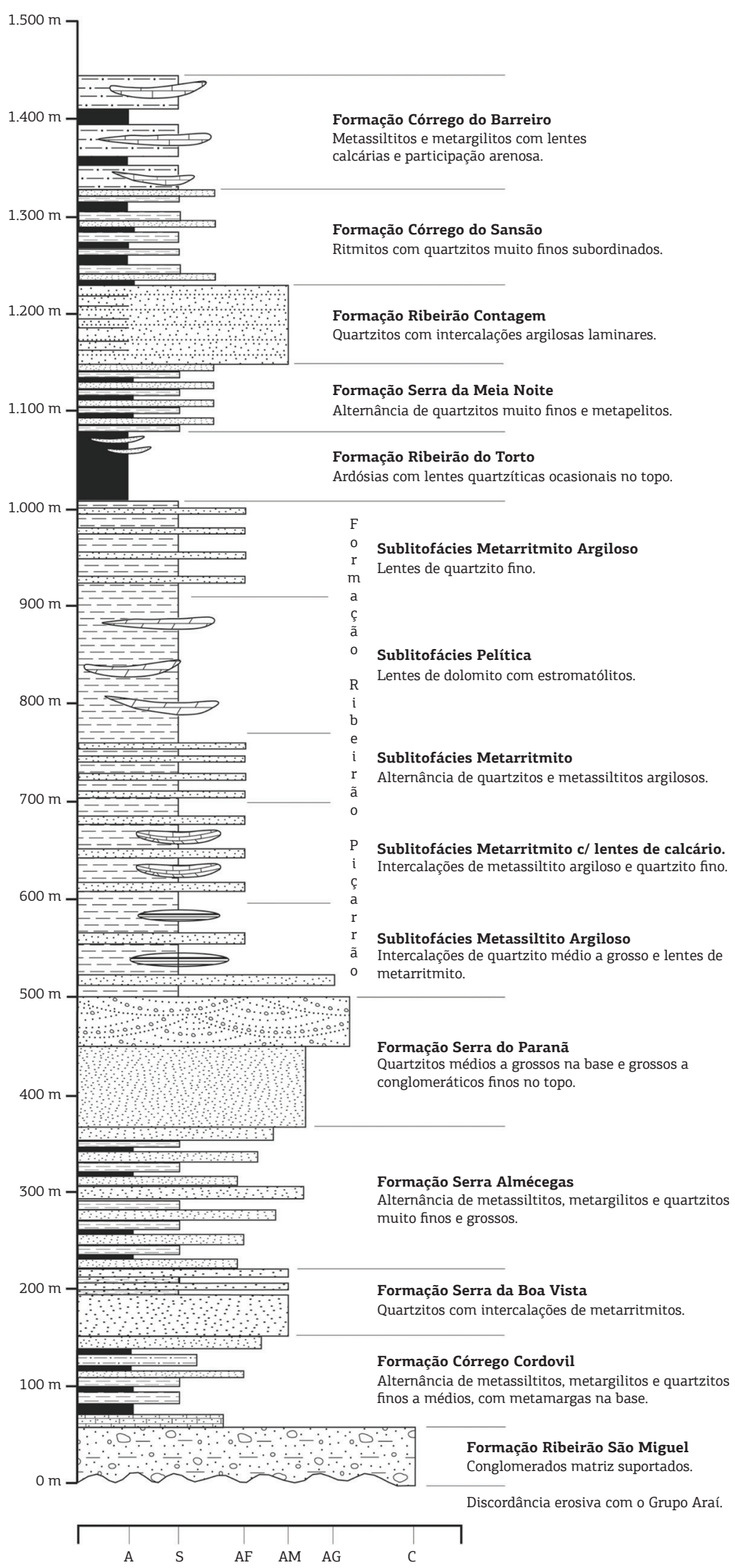

A: Argila; S: Silte; AF: Areia Fina; AM: Areia Média; AG: Areia Grossa; C: Cascalho.

Figura 2. Coluna estratigráfica do Grupo Paranoá na área-tipo de Alto Paraíso de Goiás/Distrito Federal (modificada de Faria 1995). 


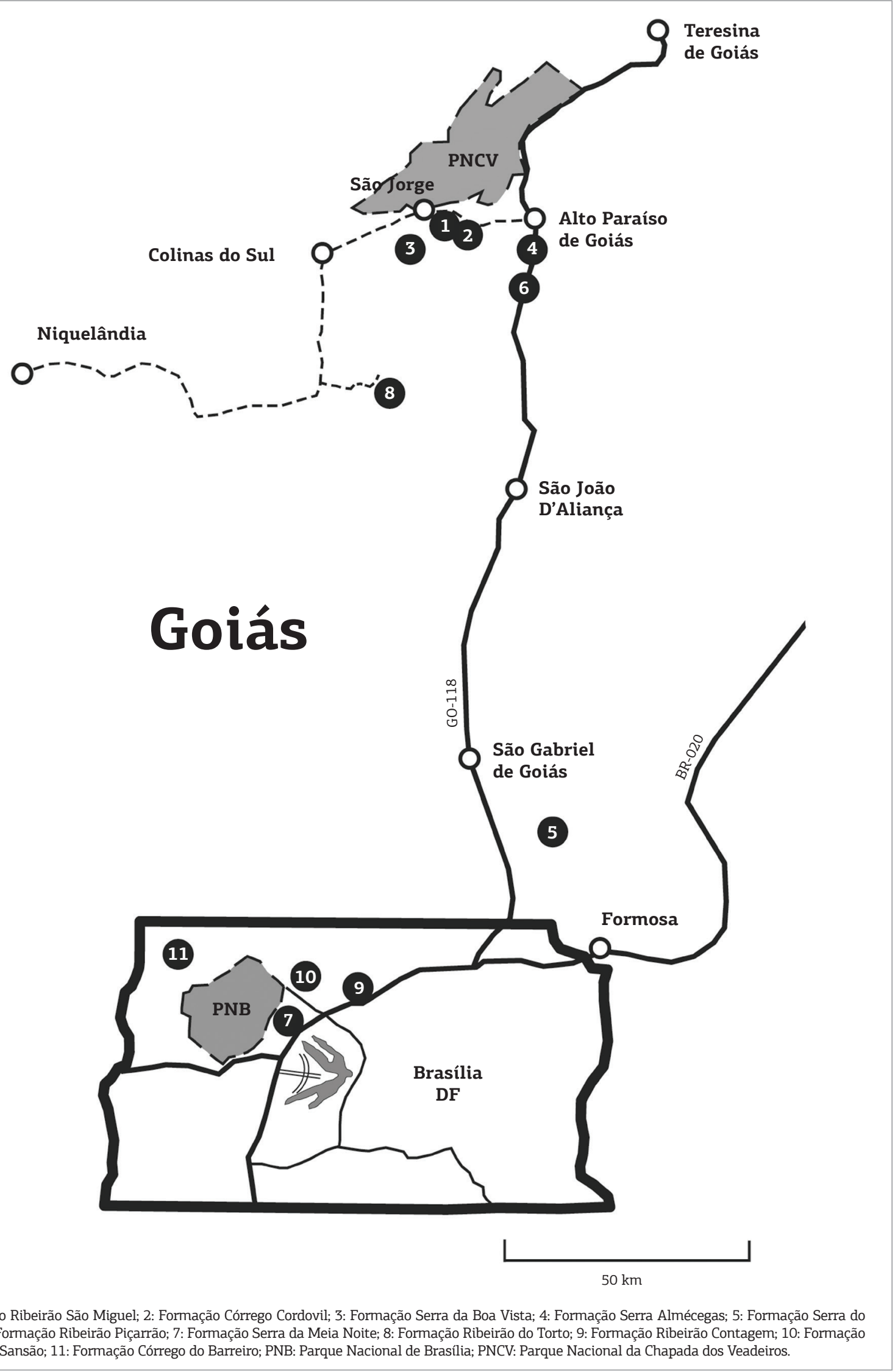

Figura 3. Localização de áreas-tipo e holoestratótipos das formações do Grupo Paranoá. 
Algumas estruturas interpretadas como clastos arredondados são, na verdade, concreçóes carbonáticas formadas durante a diagênese e litificação da rocha. Além das concreçôes, a cimentação por carbonatos resulta na precipitaçáo de grandes cristais de calcita e dolomita arroxeadas que obliteram grande parte da porosidade primária.

\section{Formação Córrego Cordovil}

A área-tipo e o holoestratótipo estão situados no baixo curso do córrego Cordovil, ao sul do Parque Nacional da Chapada dos Veadeiros. As melhores exposiçôes ocorrem entre a cachoeira do Cordovil e a foz no ribeirão São Miguel.

A litofácies típica desta unidade é representada por um metarritmito caracterizado por intercalaçôes regulares de quartzitos micáceos, finos a médios, com camadas e lâminas de metassiltitos e metassiltitos argilosos. As espessuras das camadas variam de 1 a 27 cm e a laminação interna é uma feição muito comum. Os quartzitos são, em geral, feldspáticos, o que é responsável pela tonalidade rosada das amostras de rocha intemperizadas.

Próximo à base, podem ocorrer, de forma descontínua, fácies carbonatadas materializadas por camadas de metamargas intercaladas com metassiltitos e quartzitos finos.

Além do acamamento e laminação plano-paralela, ocorrem marcas de cubos de sal, gretas de contraçáo e diques de areia na associação de estruturas sedimentares.

\section{Formação Serra da Boa Vista}

A área-tipo é a seção da Serra da Boa Vista, ao sul do Vale da Lua, e o holoestratótipo pode ser encontrado na regiáo das cachoeiras e corredeiras nos córregos Sáo Bento e Cordovil.
É representada por quartzitos finos a médios e raramente com grãos grossos e grânulos de quartzo. Esses quartzitos são brancos a cinzas em afloramentos frescos e amarelados a rosados em exposições alteradas. Os grãos são arredondados e a rocha é bem selecionada e matura, tanto textural quanto mineralogicamente.

De forma subordinada, ocorrem intercalaçóes pelíticas que formam camadas métricas de metarritmitos.

A associação de estruturas sedimentares é representada por: acamamento, laminação horizontal e ondulada, marcas onduladas assimétricas, estratificaçóes cruzadas tangenciais, tabulares e acanaladas, além de flasers e diques de areia em fácies pelíticas intercaladas.

\section{Formação Serra Almécegas}

O holoestratótipo e a área-tipo são situados nos cortes da rodovia GO-118, km 165, onde um amplo conjunto de metarrtimitos está exposto. Nessa região, também é evidente na paisagem o aspecto rítmico da rocha, onde se pode verificar o aspecto "em escada" sob o campo limpo, vegetação típica desta unidade.

É composta por metarritmitos representados por intercalaçóes de lâminas, lentes e camadas de quartzitos finos, metassiltitos argilosos e metagrauvacas quartzosas. As rochas são esverdeadas quando frescas e, em função da presença de matriz e mica detrítica, tendem a ser pouco silicificadas. De forma geral, a granulometria é psamo-pelítica e apenas localmente são encontradas fácies com grânulos e pequenos seixos de quartzo e quartzito.

Tabela 1. Formalização da estratigrafia do Grupo Paranoá para a área-tipo de Alto Paraíso de Goiás-Distrito Federal

\begin{tabular}{l|c|c|c}
\hline Nome informal & \multicolumn{1}{c}{ Nome da formação } & $\begin{array}{c}\text { Sigla da unidade } \\
\text { de mapeamento }\end{array}$ & Localidade da área-tipo/holoestratótipo \\
\hline Unidade $\mathrm{PC}$ & Formação Córrego do Barreiro & MNPpacb & Cabeceira do Córrego do Barreiro, Brazlândia, DF. \\
\hline Unidade $\mathrm{R}_{4}$ & Formação Córrego do Sansão & MNPpacs & Cabeceira do Córrego do Sansão, Sobradinho, DF. \\
\hline Unidade $\mathrm{Q}_{3}$ & Formação Ribeirão Contagem & MNPparc & Cabeceira do Ribeirão Contagem, Brasília, DF. \\
\hline Unidade $\mathrm{R}_{3}$ & Formação Serra da Meia Noite & MNPpasmn & $\begin{array}{c}\text { Estrada da Linha de Transmissão próxima ao Povoado } \\
\text { Garimpinho (Colinas do Sul), GO. }\end{array}$ \\
\hline Unidade $\mathrm{A}$ & Formação Ribeirão do Torto & MNPpart & DF 003 próximo à ponte sobre o Ribeirão do Torto, DF. \\
\hline Unidade $\mathrm{S}$ & Formação Ribeirão Piçarrão & MNPparp & GO-118, km 155 a 156. \\
\hline Unidade $\mathrm{Q}_{2}$ & Formação Serra do Paranã & MNPpasp & Cachoeira do Itiquira, GO. \\
\hline Unidade $\mathrm{R}_{2}$ & Formação Serra Almécegas & MNPpasa & Corte de Estrada na GO-118, km 165. \\
\hline Unidade $\mathrm{Q}_{1}$ & Formação Serra da Boa Vista & MNPpabv & Serra da Boa Vista a sudoeste do Vale da Lua. \\
\hline Unidade $\mathrm{R}_{1}$ & Formação Córrego Cordovil & MNPpacc & Baixo Cordovil, Chapada dos Veadeiros, GO. \\
\hline Unidade $\mathrm{SM}$ & Formação Ribeirão São Miguel & MNPparsm & Vale da Lua, Chapada dos Veadeiros, GO. \\
\hline
\end{tabular}


Nesta formação, a natureza ondulada do acamamento fica evidenciada pela presença de camadas lenticulares e alternância de filmes argilosos nas fácies mais arenosas.

O conjunto de estruturas sedimentares inclui: acamamento, lentes arenosas, estratificaçóes e laminaçóes cruzadas, diques de areia, marcas de cubo de sais, gretas de contração, marcas onduladas e flasers.

\section{Formação Serra do Paranã}

A área-tipo é o corpo principal da Cachoeira do Itiquira e o holoestratótipo pode ser observado ao longo de qualquer seção da Serra do Paraná, onde esta unidade ocorre de forma contínua e bem exposta.

É composta por quartzitos médios a grossos até conglomeráticos que ocorrem em camadas métricas internamente maciças ou laminadas. Ocorrem de forma mais comum silicificados e fraturados; nas áreas mais arrasadas, são expostos em grandes blocos. Ocorrem fácies de ortoquartzitos com grãos arredondados e esféricos e fácies de quartzitos feldspáticos com grãos mais angulosos.

Os quartzitos desta formação apresentam as seguintes estruturas sedimentares: acamamento plano-paralelo, estratificação cruzada tabular, tangencial, revirada e acanalada, canais de corte e preenchimento e raras marcas onduladas.

\section{Formação Ribeirão Piçarrão}

A área-tipo e o holoestratótipo estão situados nos cortes da estrada estadual GO-118, entre os km 155 e 156.

É composta por um conjunto de metassiltitos argilosos homogêneos com coloração cinza esverdeada a amarelada quando frescos, passando a tons rosados e vermelho escuro com o aumento da alteração intempérica. Além da litofácies típica, ainda ocorrem:

- Metassiltitos intercalados com níveis de quartzitos finos variando em espessuras desde centimétricas a decimétricas.

- Camadas decimétricas a métricas de quartzitos médios a grossos (com grãos esféricos).

- Rochas carbonáticas na forma de lentes interdigitadas a metarritmitos. Essas rochas carbonáticas podem ser micríticas ou localmente apresentar estromatólitos colunares e conophyton.

- Metarritmitos com bancos de quartzitos arcoseanos, decimétricos, geralmente rosados e comumente com aspecto maciço ou, mais raramente, finamente laminados.

Dentre as estruturas sedimentares presentes, destacamse acamamento plano-paralelo, laminação plano-paralela, laminaçôes cruzadas, laminações truncadas, marcas onduladas simétricas e raras climbing ripples.

\section{Formação Ribeirão do Torto}

A área-tipo é situada na DF-003, próximo à ponte sobre o Ribeirão do Torto, no Distrito Federal. O holestratótipo é exposto nas proximidades da Barragem de Santa Maria no interior do Parque Nacional de Brasília, onde os afloramentos nas áreas de empréstimo expóem ampla área de ardósias e sua passagem para a formação que as recobrem.

Litologicamente, esta litofácies é caracterizada por ardósias roxas quando alteradas ou cinza esverdeadas quando frescas e homogêneas, que dominam a maior parte da sucessão. Próximo ao limite com a unidade superior, ocorrem intercalaçóes síltico-argilosas milimétricas a centimétricas, com tonalidade vermelha a rosada, onde se inicia a passagem gradual para a unidade de metarritmitos que a recobre. Essas rochas se apresentam intensamente fraturadas e, em função de seu caráter pelítico, são os tipos petrográficos onde mais facilmente se desenvolvem as foliações metamórficas. Particularmente, duas superfícies são bastante penetrativas, caracterizando clivagens ardosianas típicas. A única estrutura sedimentar observada é a laminação plano-paralela, próximo ao topo da unidade.

Ocorrências de quartzitos brancos a amarelados são raras dentro do conjunto das ardósias, sendo sempre caracterizadas por lentes métricas ou decamétricas geralmente irregulares e maciças.

\section{Formação Serra da Meia Noite}

A estrada da Linha de Transmissão da Hidrelétrica Serra da Mesa, situada próximo ao Povoado do Garimpinho (município de Colinas do Sul), inclui a área-tipo e o holoestratótipo desta formação.

É caracterizada por alternâncias de estratos centimétricos a métricos de quartzitos finos a médios com níveis geralmente mais delgados de metassiltitos argilosos, metalamitos siltosos e metalamitos micáceos. A quantidade relativa de termos arenosos é sempre importante, justificando, assim, a denominação deste pacote como unidade de metarritmito arenoso.

Além dos estratos decimétricos a métricos, duas camadas de quartzito com coloração branca/ocre, granulação fina a média e espessura variável entre 8 e 20 m se destacam próximo à base e no topo desta formação.

A interestratificação dos diferentes tipos petrográficos que compóem os metarritmitos é representada por estratos de 1 a $5 \mathrm{~cm}$ de espessura, onde localmente é possível observar o caráter granocrescente do conjunto. Raramente, são observadas camadas e lentes de quartzito muito grosso a conglomerático, com seixos de quartzo e quartzito arredondados e esféricos. $\mathrm{O}$ acunhamento lateral e o aspecto lenticular de alguns estratos são feiçóes bastante comuns. 
As estruturas sedimentares do tipo estratificaçóes plano-paralelas, marcas onduladas (simétricas e assimétricas com cristas sinuosas ou paralelas), estratificaçôes lenticulares e diques de areia são bastante frequentes na Formação Serra da Meia Noite, enquanto as laminaçóes cruzadas e truncadas por ondas, estratificaçóes sigmoidais, hummockys e estratificaçóes do tipo Swaley são mais raras.

\section{Formação Ribeirão Contagem}

A exposição-tipo desta formação é localizada na região de nascente do Ribeirão Contagem, no Distrito Federal. Apresenta contato brusco e concordante com a Formação Serra da Meia Noite.

Esta unidade sustenta as áreas de chapadas elevadas do Distrito Federal e nos municípios Planaltina de Goiás e São João D’Aliança, onde comumente é recoberta por solos espessos.

Esta formação é caracterizada por quartzitos finos a médios, brancos ou cinza claro (cinza escuro quando frescos), bem selecionados, maturos mineralogicamente, em geral muito silicificados e, onde se encontram menos recristalizados, mostram grãos arredondados. Seu aspecto maciço é constante na maioria das exposiçóes, sendo atribuído à intensa silicificação. Localmente, em condiçôes de maior intemperismo, é possível identificar o acamamento plano-paralelo em bancos decimétricos a métricos. Muitas vezes, o acamamento original é de difícil percepção em virtude da silicificação e do intenso fraturamento, comumente desenvolvidos nesta litofácies. Além do acamamento, são observadas estratificaçóes cruzadas de pequeno a médio porte e de caráter variado, sendo comuns as tabulares, tangenciais, acanaladas e do tipo espinha de peixe, além de raras marcas onduladas assimétricas de cristas sinuosas ou paralelas. A estruturação interna de algumas estratificações tipo espinha de peixe mostra, raramente, a presença de estruturas tipo tidal bundles.

Lentes de metarritmitos, com espessuras variando de decimétricas até $10 \mathrm{~m}$ (comumente interceptadas por poços tubulares profundos), ocorrem geralmente próximas à base e ao topo desta sucessão de quartzitos.

As seçôes delgadas de amostras desta unidade mostram a intensa silicificação já observada nos afloramentos. A forma dos grãos e seu contato não são mais aqueles originais, tendo sido intensamente modificados pelo metamorfismo; contudo, o alto grau de selecionamento pode ser ainda observado em amostras que exibem sobrecrescimento marcado por uma fina película de óxidos em torno do grão original. Além do quartzo, que, via de regra, perfaz mais de $95 \%$ do arcabouço, ocorrem grãos de feldspatos muito alterados, nas seçóes estudadas, e muscovita detrítica, além de minerais opacos, turmalina e zircão.

\section{Formação Córrego do Sansão}

Os afloramentos na região da cabeceira do Córrego do Sansão, Sobradinho, DF, são considerados como a área-tipo desta unidade e seu holoestratótipo está situado no corte da DF $330 \mathrm{~km} \mathrm{4,5}$, onde um conjunto de metarritmitos dobrados encontra-se bem exposto.

É bem exposta em áreas dissecadas que se sucedem às chapadas sustentadas pelos quartzitos da Formação Ribeirão Contagem. Seu contato com a unidade sotoposta é nitidamente gradacional e se deve ao afogamento rápido da plataforma.

É representada por metarritmitos homogêneos com intercalações centimétricas regulares de metassiltitos, metalamitos e quartzitos finos que apresentam coloração cinza, amarelada, rosada ou avermelhada em função dos diferentes graus de intemperismo. Raros bancos (de 0,5 até 1,0 m) de metassiltitos maciços amarelados ou rosados e de quartzitos finos, feldspáticos e rosados ocorrem localmente, quebrando a regularidade das camadas rítmicas centimétricas.

Dentre as estruturas sedimentares, são comuns as estratificaçóes plano-paralelas, níveis ricos em estruturas do tipo lentes arenosas, climbing ripples, hummockys de pequeno porte, raras marcas onduladas de oscilação (simétricas) e pequenas sigmoides geralmente amalgamadas em bancos mais espessos. Comumente, é possível observar que os bancos arenosos apresentam base plana e topo ondulado.

Os níveis de quartzitos são mal selecionados e sempre apresentam concentraçóes variáveis de material pelítico intersticial aos grãos de quartzo. A recristalização de grãos é comum, sendo localmente possível observar sobrecrescimento. Proporçóes entre 5 e 10\% de feldspatos (sendo o plagioclásio mais comum) permitem enquadrar os protolitos dos níveis quartzíticos como arenitos feldspáticos. Nos casos onde o material pelítico ultrapassa os $15 \%$, o protolito é representado por grauvaca quartzosa. Os níveis pelíticos mostram apenas algumas lamelas de muscovita detrítica em meio a uma massa de óxidos e hidróxidos de ferro, provavelmente resultante da alteraçáo dos filossilicatos e argilo-minerais originais da rocha.

\section{Formação Córrego do Barreiro}

A área-tipo está situada nas cabeceiras do Córrego do Barreiro, a norte da cidade de Brazlândia, no Distrito Federal.

Apresenta contato transicional com a Formação Córrego do Sansão marcado pelo aumento progressivo na ocorrência dos metargilitos sobre os quartzitos e metassiltitos.

Litologicamente, é representada principalmente por metalamitos siltosos de coloração cinza prateado (que passa a amarelo, rosado ou avermelhado com a alteração) bastante laminados, podendo mostrar foliaçóes e, por vezes, aspecto sedoso ao tato devido à abundante presença de filossilicatos. 
Este tipo litológico é o mais comum nesta formação, contribuindo com cerca de $85 \%$ do total da sucessão.

Além dos metapelitos, ocorrem rochas carbonáticas e quartzíticas. As rochas carbonáticas são representadas por calcários pretos ou cinza escuros, micríticos ou intraclásticos (classificados como mudstones, grainstone intraclásticos, packstone intraclásticos e floatstones intraclásticos) e subordinadamente por dolomitos com tons cinza claros, localmente estromatolíticos. Sua geometria lenticular é facilmente interpretada em função do padrão de afloramentos que mostra clara interdigitação com as fácies pelíticas. As lentes apresentam diâmetros de centenas de metros, podendo as maiores alcançar mais de um quilômetro. Não raramente, os calcários e os dolomitos apresentam delgadas lâminas de material argiloso, marcando o acamamento primário. Brechas calcárias muitas vezes silicificadas são distribuídas sem controle estratigráfico definido, tendo sido observadas próximo às bordas de algumas lentes ou em posiçóes mais baixas topograficamente, possivelmente na base de ciclos carbonáticos. $\mathrm{Na}$ região de interdigitação entre as lentes carbonáticas e as rochas pelíticas, são comuns as fácies de metamargas com aspecto maciço quando frescas e poroso quando alteradas.

Os estromatólitos observados nestes carbonatos são relativamente abundantes e são compostos por estromatólitos com laminaçóes diversificadas: estromatólitos colunares, estromatólitos cônicos (conophyton) e estromatólitos caracterizados por esteiras horizontais.

Os quartzitos observados na Formação Córrego do Barreiro ocorrem em lentes alongadas métricas até decamétricas ou em níveis centimétricos contínuos lateralmente que podem apresentar certo ritmo. Trata-se de quartzitos médios, grossos a conglomeráticos, mal selecionados, preto a cinza escuro (em função de uma película de matéria orgânica em torno dos grãos detríticos) e feldspáticos, com clastos subangulosos a arredondados. Este tipo litológico não é comum em afloramentos, uma vez que são facilmente desagregáveis; contudo, são muito comumente observados em amostras de calha de poços tubulares profundos. Os quartzitos e conglomerados finos, muitas vezes, apresentam matriz pelítica de coloração rosada ou ocre. A análise em lâminas delgadas (apenas duas amostras) mostra grãos arredondados, com contatos desde planares até suturados.

\section{SISTEMAS DEPOSICIONAIS}

O conjunto de estruturas sedimentares, os litotipos, variaçôes e interdigitaçôes, além da continuidade lateral das litofácies, permitem posicionar a sedimentação em ambientes marinhos com lâmina d'água variável, caracterizando ciclos transgressivos/regressivos.

\section{Formação Ribeirão São Miguel}

A associação faciológica, sua relação de interdigitação, a análise petrográfica microscópica e as estruturas sedimentares observadas permitem interpretar a deposição por leques aluvionares. A sucessão de fácies permite estabelecer uma arquitetura clássica de leque aluvial completo, com ruditos mais grossos representando as porçôes proximais e medianas do leque e as fácies laminadas e de grauvacas, as suas porçôes distais.

A grande quantidade de material matricial (matriz areno-silto-carbonática) indica que o processo deposicional por fluxos de detritos subaéreos foi o principal mecanismo de transporte e sedimentação. As correntes subaquosas foram subordinadas, o que é evidenciado pela presença de fácies laminadas, contendo eventuais clastos mais arredondados.

Esta formação marca o início da deposição do Grupo Paranoá, em condiçóes continentais, as quais foram substituídas de forma rápida por uma transgressão marinha, dando lugar à sedimentação plataformal.

A fonte dos sedimentos da Formação Ribeirão São Miguel é exclusivamente representada por fragmentos de rochas do Grupo Araí, com maior contribuição das unidades de metassiltito superiores, quartzitos e lentes de rochas carbonáticas. O carbonato presente em grande concentração na matriz dos conglomerados ou na forma de cimento é oriundo de lentes de calcários e mármores comumente observados no topo do Grupo Araí.

\section{Formações Córrego Cordovil e Serra Almécegas}

Por se tratar de unidades muito similares em termos petrográficos e quanto à associação de estruturas primárias, o ambiente deposicional é considerado o mesmo.

A atuação cíclica de processos trativos e suspensivos, a granulometria das litofácies e a presença abundante de muscovita detrítica são compatíveis com deposição em planícies de marés. Nestes sítios amplos e rasos, há alternância de deposição por agradação vertical responsável pela formação das camadas de metassiltitos argilosos e filmes argilosos intercalados às camadas arenosas. As lentes arenosas são resultantes do aumento de energia com erosão e retrabalhamento de camadas arenosas contínuas.

A exposição ocasional da plataforma é materializada pela presença de pseudomorfos de cubos de sal e gretas de contração e mostra que a região tinha águas rasas associadas a elevaçôes paleogeográficas do substrato da bacia. 
Nesses casos, qualquer rebaixamento da lâmina d'água era responsável pela exposição subaérea de lamas.

\section{Formação Serra da Boa Vista:}

A granulometria fina dos quartzitos e a constante presença de filmes argilosos, camadas pelíticas e estruturas flaser indicam se tratar de condiçóes de sedimentação de supramaré. Neste ambiente, há retrabalhamento de areias por ondas e acumulação esporádica de argila/silte em momentos de marés de sizígia em que os elevados níveis de preamar eram responsáveis pela acumulação de lamas em porçóes de águas muito rasas ou permanentemente expostas.

Os níveis com grãos de areia grossa ocasionalmente encontrados são atribuídos a aporte fluvial de maior energia (rios entrelaçados), cuja carga de leito era dissipada ao longo da linha de costa.

\section{Formação Serra do Paranã}

O conjunto de estruturas sedimentares, a granulometria dos psamitos e a elevada maturidade permitem enquadrar a deposição desta formação a sistema de supramaré sob ação de ondas e marés. Este ambiente, com predomínio de atuação de processos trativos, foi responsável pelo retrabalhamento prolongado de areias médias e grossas trazidas por sistemas fluviais.

A presença de estratificação cruzada revirada e de canais de corte e preenchimento indica ciclos de aumento de energia, provavelmente associados a canais de marés.

\section{Formação Ribeirão Piçarrão}

O grande volume de pelitos sugere tratar-se de sedimentação em águas calmas, sob lâmina d'água com profundidade equivalente à da plataforma externa (condiçóes de inframaré), abaixo da atuação de ondas de tempo bom. $\mathrm{O}$ aspecto maciço da maior parte dos metassiltitos permite inferir que o processo deposicional dominante foi a decantação por gravidade de fluxos de baixa densidade (migração de plumas de lama a partir da plataforma interna).

Os ritmitos das subtitofácies metarrítmicas são mal expostos, dificultando sua caracterização ambiental. Como não foram observadas estruturas como hummocky ou estratificaçôes tipo Swely (atuação simultânea de correntes de tração e oscilação), estas subunidades são consideradas como resultantes da deposição por rápidas regressóes que, causando diminuição da profundidade da lâmina d'água, proporcionou o retrabalhamento e deposição de areias intercaladas a lamas.

Os calcários, ocasionalmente observados, devem corresponder a picos regressivos, que possibilitaram a deposição de lamas micríticas nas porçôes mais rasas da plataforma.
Apesar do grande recuo da linha de costa, não foram observadas situaçóes de exposição subaérea.

\section{Formação Ribeirão do Torto}

Corresponde a litofácies de condiçôes sublitorâneas de inframaré, posicionada na plataforma externa. É a unidade depositada em águas mais profundas e de menor energia em toda a Bacia Paranoá, permanentemente abaixo da atuação de bases de ondas. O processo deposicional foi dominado por agradação vertical de argilas, que resultava em folhelhos escuros, provavelmente muito laminados.

Os raros corpos arenosos maciços, observados em afloramentos e testemunhados por poços, são interpretados como o registro de fluxos discretos por correntes de turbidez diluídas (pequena densidade), geradas por tempestades atuantes em regióes mais rasas da plataforma.

\section{Formação Serra da Meia Noite}

Representam depósitos litorâneos em condiçóes inframaré, onde os bancos arenosos apenas eram ocasionalmente retrabalhados pela base das maiores ondas. A maior parte das areias desta unidade foi depositada pela ação de tempestades atuando nas porçôes mais rasas da plataforma, transportando e depositando areais em sítios onde, em condiçóes normais, não ocorre deposição de psamitos. Este ambiente gera estratificaçóes sigmoidais e do tipo hummocky.

Os quartzitos de maior espessura individualizados nesta unidade são interpretados como dois instantes de rápido raseamento da bacia, tendo sido depositados em condiçôes de maior energia. A pequena proporção de micas e minerais instáveis nas intercalaçóes arenosas mostra que não havia aporte proximal de detritos, indicando que as areias eram progressivamente retrabalhadas em condiçóes litorâneas, resultando no aumento de sua maturidade mineralógica.

\section{Formação Ribeirão Contagem}

As feiçóes sedimentares (geometria tabular e estratificaçôes cruzadas), granulometria dos arenitos originais e a análise microscópica possibilitam posicionar sua sedimentação em condiçôes de plataforma interna com deposição dominada por correntes trativas, sob condiçôes litorâneas rasas de intermaré. Possivelmente, atuavam correntes canalizadas vinculadas a atividade de marés, responsáveis pela migração de formas de leito que formavam os estratos cruzados acanalados e tangenciais e retrabalhamentos por base de ondas, formando os canais de corte e preenchimento. As estratificaçóes tipo espinha de peixe indicam a atuação de retrabalhamentos por marés. 
Os raros pacotes de metarritmitos são interpretados como rápidos afogamentos das porçóes rasas da plataforma interna (rápidas transgressôes marinhas) com considerável aumento de profundidade da lâmina d'água.

\section{Formação Córrego do Sansão}

Em função da ampla predominância de pelitos e da geometria dos corpos arenosos, além das estruturas sedimentares associadas, a unidade foi interpretada como depositada em uma planície de maré sob condições de intermaré. Ocasionalmente, ocorriam retrabalhamentos por tempestades como atestados pelas pequenas hummockys presentes em leitos arenosos. Truncamentos por ondas são evidenciados pelas climbing ripples e pelas marcas onduladas.

A presença de lentes arenosas em meio a um conjunto pelítico, observadas em certos intervalos, indica condiçôes de águas mais profundas (intermaré).

\section{Formação Córrego do Barreiro}

Ao contrário das demais unidades, a sedimentaçáo deste conjunto sofreu forte influência da paleogeografia de fundo, correspondendo ao final do preenchimento da Bacia Paranoá. Os sedimentos carbonáticos eram depositados nos altos, sob condiçóes de águas rasas, quentes e limpas, enquanto os pelitos sedimentavam nas águas mais profundas abaixo da atuação de base de ondas.

Os depósitos carbonáticos com intraclastos evidenciam o retrabalhamento dos calcários micríticos. As lentes carbonáticas, em situação de maior restrição, sofriam dolomitização eodiagenética. A presença dos estromatólitos também mostra se tratar de carbonatos de águas rasas com lâmina d'água de até $20 \mathrm{~m}$ para o crescimento das formas cônicas ou ainda mais rasas para o crescimento das formas colunares.

A grande proporção de pelitos evidencia áreas fontes já bastante arrasadas e deposição em águas mais profundas equivalente a condiçóes inframaré.

Os quartzitos são interpretados como canais de fundo que, aparentemente, recortavam a plataforma mista (siliciclástica/carbonática) em direçóes variadas. O elevado grau de arredondamento e esfericidade indica tratar-se de material ressedimentado, possivelmente caracterizado pelo retrabalhamento de outros sedimentos grossos. O forte odor exalado de blocos de quartzitos recém-partidos deve corresponder a gás oriundo de matéria orgânica dos calcários ou pelitos, armazenado nestas litologias por possuírem maior porosidade.

\section{ANÁLISE DO TRATO DE SISTEMAS}

A análise conjunta das várias litofácies mostra deposição em condiçóes plataformais com constantes variaçóes de profundidade da lâmina d'água, depois da sedimentação em ambiente continental associado a leques aluvionares.

A Fig. 4 ilustra de forma esquemática os limites das seis parassequências consideradas para a sequência deposicional do Grupo Paranoá. O controle tectônico sin-deposição é limitado, o que resulta em uma bacia de margem passiva de mar epicontinental (substrato representado por crosta continental) e subsidência flexural predominante. Falhas sin-deposicionais ocorrem apenas na etapa inicial da deposição, funcionando como controle para a formação dos leques aluvionares responsáveis pela sedimentação da Formação Ribeirão São Miguel.

Quatro ciclos transgressivos e três regressivos podem ser delimitados a partir da litoestratigrafia observada na porção marinha do Grupo Paranoá, sendo que os rápidos afogamentos da plataforma representam o principal critério utilizado para a separação de tais ciclos. O primeiro ciclo transgressivo é evidenciado pelo aprofundamento da bacia durante a sedimentação da Formação Córrego Cordovil; nesta fase, é marcante o processo de exposição subaérea responsável pela formação de marcas de cubos de sais e gretas de contração.

Em seguida, observa-se o raseamento da plataforma com migração da linha de costa em direçáo ao mar, quando são depositados os psamitos laminados da Formação Serra da Boa Vista. A condição muito rasa das águas permite a preservação de gretas de ressecamento e marcas de cubos de sais.

Nova rápida transgressão resulta em novo aprofundamento da plataforma e deposiçáo de sedimentos psamo-pelíticos da Formação Serra Almécegas. Ciclos de menor ordem permitem que ocorra exposição subaérea em sítios isolados da plataforma. Em seguida, há aumento de entrada de material terrígeno mais grosso com areia grossa e grânulos, fortemente retrabalhados por marés em águas rasas a muito rasas (plataforma dominada por marés, com planície e canais), preservados na Formação Serra do Paranã.

O ciclo seguinte representa o maior afogamento sofrido pela plataforma e foi responsável pela deposição das formaçôes Ribeirão Piçarrão e Ribeirão do Torto. Neste estágio, são marcantes dois ciclotemas regressivos próximo à base e ao topo da Formação Ribeirão Piçarrão. Os corpos arenosos ocasionalmente encontrados na Formação Córrego do Torto são interpretados como eventos turbidíticos que ocorrem em porçôes mais profundas da plataforma.

O ciclo regressivo seguinte é iniciado pela passagem gradacional entre as formaçóes Córrego do Torto e Serra da Meia Noite e encerra no topo da Formação Córrego Contagem. Rápidas transgressóes (em ciclos de menor ordem) são responsáveis pela deposição de metarritmitos intercalados na Formação Córrego Contagem. O último ciclo 


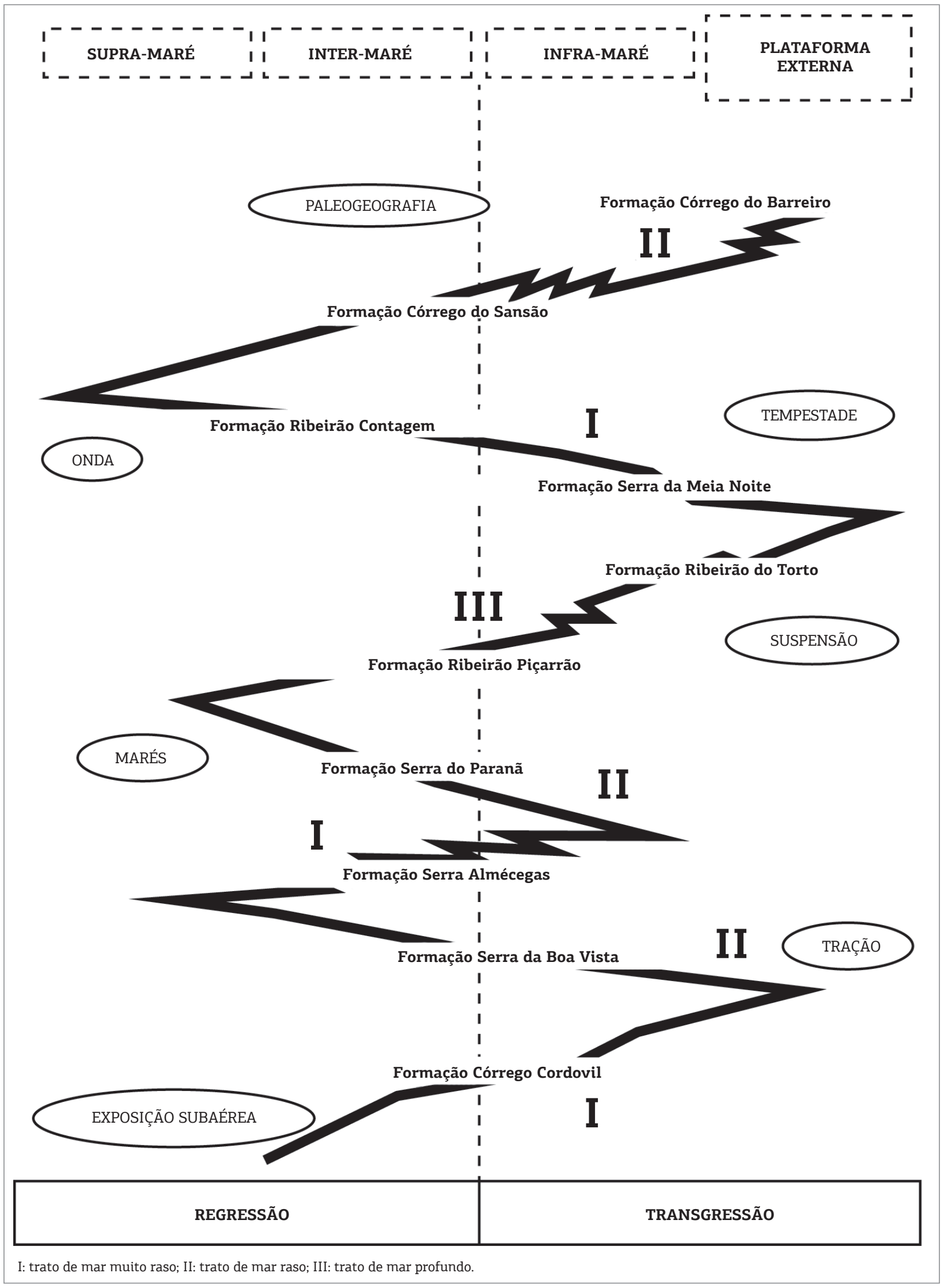

Figura 4. Representação esquemática do trato de sistemas marinhos associado à deposição do Grupo Paranoá. Os termos em caixas tracejadas representam ambientes deposicionais e os termos na elipse representam processos/controles deposicionais. 
regressivo inicia na base da Formação Serra do Sansão, após rápido afogamento da plataforma, culminando com os estágios finais de sedimentação dos carbonatos de águas rasas da Formação Serra do Barreiro.

O conjunto das litofácies descritas caracteriza uma única sucessão deposicional denominada de Sequência Paranoá. As passagens entre litofácies que marcam rápidos episódios de aumento da lâmina d'água definem os vários ciclos e são consideradas como os limites de parassequências, pois caracterizam superfícies de máxima inundação lateralmente persistentes e observadas por toda a extensão da Bacia Paranoá.

\section{CORRELAÇÕES REGIONAIS}

O Grupo Paranoá apresenta algumas diferenças quando comparadas as diferentes áreas de exposição. Os principais contrastes são relacionados a variaçóes de granulometria, presença de litofácies em áreas específicas, grau metamórfico e desenvolvimento de sedimentação carbonática (na seção de topo do grupo).

$\mathrm{Na}$ região de Cabeceiras-Unaí, no estado de Minas Gerais, ocorre em posição estratigráfica da seção de topo do Grupo Paranoá, uma litofácies denominada Nível Arcoseano (Guimarães 1997), a qual não está presente na seção tipo de Alto Paraíso, Distrito Federal. Esta litofácies apresenta granulometria grossa, com presença comum de grânulos e pequenos seixos de quartzo, quartzito e feldspato. Esta unidade ocorre ainda no estado de Goiás, em Cristalina e ao norte de Formosa (distritos de JK e Bezerra). A presença desta litofácies é interpretada como resultante de soerguimentos localizados na área fonte, que proporcionaram o transporte de material grosso até a plataforma.

No limite das porçóes interna e externa da Faixa Brasília (região de Quebra Linha-Niquelândia), o Grupo Paranoá apresenta a seção de topo bastante desenvolvida. Nessa região, Fuck et al. (1988) identificaram três unidades ricas em rochas carbonáticas (grandes lentes de metacalcários e metadolomitos) inseridas nas unidades F, G, H e I. Toda essa sucessão corresponde à Formação Córrego do Barreiro, sendo que seu desenvolvimento mais amplo é interpretado como condicionado à presença de altos de relevo na paleogeografia de fundo da bacia.

Nas regióes dos domos de Caldas Novas e Cristalina, a presença do Grupo Paranoá é inequívoca e a correlação é associada à porção de topo da estratigrafia da área-tipo de

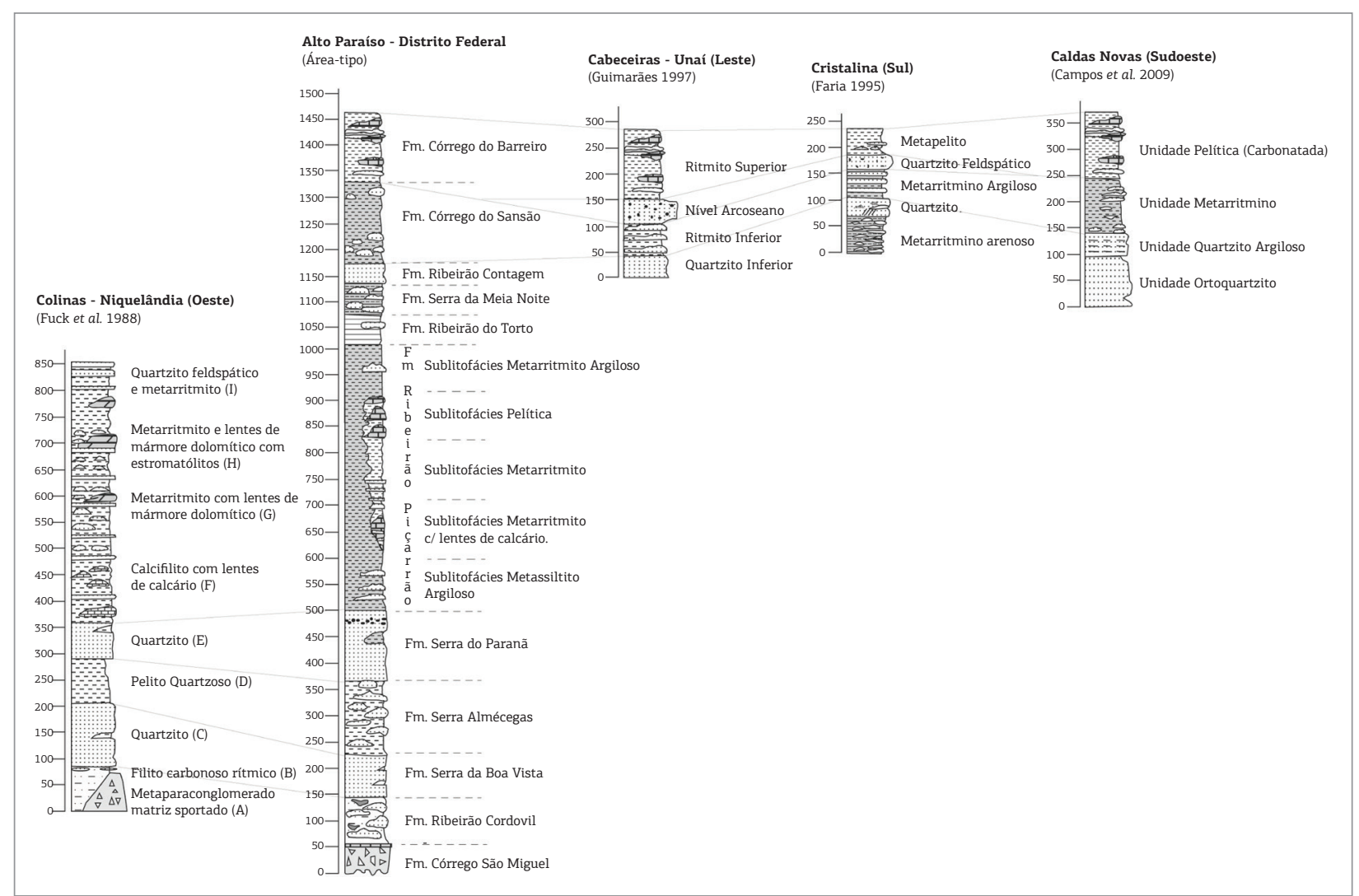

Figura 5. Correlação regional do Grupo Paranoá em diferentes áreas de ocorrência. Área-tipo de Alto Paraíso-Distrito Federal com as áreas de Colinas-Niquelândia (Fuck et al. 1988); Cabeceiras-Unaí (Guimarães 1997); Cristalina (Faria 1995); Caldas Novas (Campos et al. 2009). Fm.: Formação. 
Alto Paraíso de Goiás, Distrito Federal. Em Caldas Novas, as unidades Ortoquartzito, Quartzito Argiloso e PelitoCarbonatada são correlacionáveis, respectivamente, às formações Ribeirão Contagem, Córrego do Sansão e Córrego do Barreiro. Em Cristalina, são esperadas as seguintes correlações: Unidade Metarritmito Arenoso $\rightarrow$ Formação Serra da Meia Noite; Unidade Quartzito $\rightarrow$ Formação Ribeirâo Contagem; Unidade Metarritmito Argiloso $\rightarrow$ Formação Córrego do Sansão; Quartzito Felsdspático $\rightarrow$ sem correlação com a área-tipo e Unidade Metapelito $\rightarrow$ Formação Córrego do Barreiro.

A Fig. 5 mostra a correlação entre as principais seçôes regionais do Grupo Paranoá.

\section{CONSIDERAÇÕES FINAIS}

A formalização da estratigrafia do Grupo Paranoá deverá facilitar as correlaçóes entre as diferentes áreas de ocorrência do Grupo Paranoá. O uso de termos associados a acidentes geográficos para a nomenclatura das áreas-tipo permite o acesso de pesquisadores e demais usuários da informação geológica a pontos específicos, com a observação de todo o conjunto de litofácies de cada unidade.

A deposição do Grupo Paranoá ocorreu em uma bacia de margem passiva, sob subsidência flexural, com forte influência de processos marinhos em regimes ora retrogradacionais, ora progradacionais, resultando em um preenchimento sedimentar com ampla continuidade lateral.

A associação de dados relativos à presença de conophyton do gênero Metulum (Cloud \& Dardenne 1973, Dardenne et al. 1976) com os dados isotópicos em zircôes detríticos (Matteini et al. 2012) indica que o Grupo Paranoá foi depositado no Mesoproterozoico entre 1.300 e $1.042 \mathrm{Ma}$

A nomenclatura formal também deverá dar suporte a estudos derivados da cartografia geológica, como os mapas hidrogeológico e de geodiversidade, os quais podem aproveitar as designaçóes apresentadas para as unidades hidroestratigráficas e de geotopos.

Por fim, as denominaçóes formais ajustam a proposta de Faria (1995) ao código brasileiro de nomenclatura estratigráfica e facilitam as correlaçóes regionais relativas às diferentes áreas de ocorrência do Grupo Paranoá.

\section{REFERÊNCIAS}

Andrade Ramos J.R. 1956. Folha Geológica da Nova Capital. Rio de Janeiro, DNPM/DGM. p. 55-58. (Relatório Anual do Diretor, ano de 1956).

Andrade Ramos J.R. 1958. Folha geológica da nova capital. Rio de Janeiro, DNPM/DGM. p. 44-46. (Relatório Anual do Diretor, ano de 1957).

Baeta Jr. J.D.A., Fogaça C.C., Ramos J.B., Jo J.A.G. \& Barberi M. 1978. Projeto manganês no centro-sul de Goiás. Relatório Final. Goiânia, DNPM/CPRM, v.7, $98 \mathrm{p}$

Braun O.P.G. \& Baptista M.B. 1978. Considerações sobre a geologia pré-cambriana da Região Sudeste e parte da Região Centro Oeste do Brasil. In: Reunião Preparatória para o Simpósio sobre o Cráton do São Francisco e suas Faixas marginais, 1977. Salvador. Anais... Salvador, Sociedade Brasileira de Geologia, p.225-368.

Braun O.P.G., Martins M. \& Oliveira W.J. 1993. Continuidade das seqüências rifeanas sob a Bacia do São Francisco constatada por levantamentos geofísicos em Minas Gerais. In: Simpósio sobre o Cráton do São Francisco, 2., 1993. Salvador. Anais... Salvador, Sociedade Brasileira de Geologia, p. 164-166.

Campos J.E.G., Monteiro C.F. \& Dardenne M.A. 2005. Conglomerado São Miguel no Vale da Lua, sul da Chapada dos Veadeiros, GO - Cenário exótico de rara beleza modelado pela erosão fluvial. In: Winge M., Schobbenhaus C., Berbert-Born M., Queiroz E.T., Campos D.A., Souza C.R.G. \& Fernandes A.C.S. (orgs.). Sítios geológicos e paleontológicos do Brasil. v. 1.Rio de Janeiro, CPRM - CEDOC, p. 45-53.

Campos J.E.G., Tröger U. \& Haesbaert F.F. 2009. Águas Quentes de Caldas Novas, Goiás. Notável ocorrência de águas termais sem associação com magmatismo. In: Winge M., Schobbenhaus
C., Berbert-Born M., Queiroz E.T., Campos D.A., Souza C.R.G. \& Fernandes A.C.S. (orgs.). Sítios geológicos e paleontológicos do Brasil. v. 2. Rio de Janeiro, CPRM - CEDOC, p. 177-190.

Cloud P. \& Dardenne M.A. 1973. Proterozoic age of the Bambui Group in Brazil. Geological Society of America Bulletin, 84:673-676.

Condé V.C., Campos J.E.G., Dardenne M.A. \& Faria A. 1994 Posicionamento estratigráfico das unidades do Grupo Paranoá na Serra Geral do Paranã, a leste da cidade de São Gabriel - GO. In: Simp. Geol. Centro-Oeste, 4., 1994. Brasília. Boletim... Brasília, Sociedade Brasileira de Geologia, p. 164-165.

Costa M.T. \& Branco J.J.R. 1961. Roteiro da excursão Belo HorizonteBrasília-Belo Horizonte. Inst. Pesq. Radioativas/UFMG. Contribuição ao XIV Congr. Bras. Geol. Publicação 5. 126p.

Dardenne M.A. 1978. Síntese sobre a estratigrafia do Grupo Bambuí no Brasil Central. In: Congresso Brasileiro de Geologia, 30., 1978. Recife Anais... Recife, Sociedade Brasileira de Geologia, v. 2, p. 597-610

Dardenne M.A. 1979. Les minéralisations plomb, zinc, fluor du Protérozoïque Supérieur dans le Brésil Central. These de Doctorat d’Etat, Université Pierre et Marrie Curie - Paris VI, Paris, 251p.

Dardenne M.A., Faria A. \& Andrade G.F. 1976. Occurrence de stromatolites columnaires dans Le Group Bambuí (Goiás, Brésil). Anais da Academia Brasileira de Ciências, 48(3):555-566.

Dardenne M.A., Mello S.M.G. \& Moeri E. 1972. Conophyton: um fóssil index do Precambriano no Grupo Bambuí. Ciência e Cultura 23(2):199-203 
Dyer R.C. 1970. Notas sobre o conglomerado São Miguel, basal da Formação Paranoá. Revista da Escola de Minas, 28:27-30.

Faria A. 1995. Estratigrafia e sistemas deposicionais do Grupo Paranoá nas áreas de Cristalina, Distrito Federal e São João D’Aliança-Alto Paraíso de Goiás. Tese de Doutorado, Instituto de Geociências, Universidade de Brasília, Brasília, 199 p.

Freitas-Silva F.H. \& Campos J.E.G. 1995. Geologia do Parque Nacional de Brasília - DF. Boletim de Geociências do Centro-Oeste, 18(1/2):32-43.

Freitas-Silva F.H. \& Campos J.E.G. 1998. Geologia do Distrito Federal. In: Inventário Hidrogeológico e dos recursos hídricos superficiais do Distrito Federal. Brasília, SEMARH, v. 1, p. 1-86.

Fuck R.A., Marine J.O., Dardenne M.A. \& Figueiredo A.N. 1988. Coberturas metassedimentares do Proterozóico Médio: os grupos Araí e Paranoá na região de Niquelândia - Colinas, Goiás. Revista Brasileira de Geociências, 18(1):54-62.

Guimarães E.M. 1997. Estudos de proveniência e diagênese com ênfase na caracterização dos filossilicatos dos Grupos Paranoá e Bambuí, na região de Bezerra-Cabeceiras (GO). Tese de Doutorado, Instituto de Geociências, Universidade de Brasília, Brasília, 270 p.

Laranjeira N.P.F. 1992. A Plataforma mista de siliciclásticos e carbonatos do Grupo Paranoá na região de Unaí - MG. Dissertação de Mestrado, Instituto de Geociências, Universidade de Brasília, Brasília, 207 p.
Martins-Neto M.A. 2009. Sequence stratigraphic framework of Proterozoic successions in eastern Brazil. Marine and Petroleum Geology, 26(2):163-176.

Matteini M., Dantas E.L, Pimentel M.M., Alvarenga C.J.S. \& Dardenne M.A. 2012. U-Pb and Hf isotope study on detrital zircons from the Paranoá Group, Brasília Belt Brazil: constraints on depositional age at Mesoproterozoic-Neoproterozoic transition and tectono-magmatic events in the São Francisco craton. Precambrian Research, 206-207:168-181.

Pimentel M.M., Dardenne M.A., Fuck R.A., Viana M.G., Junges S.L., Fischel D.P., Seer H. \& Dantas E.L. 2001. Nd isotopes and the provenance of detrital sediments of the Neoproterozoic Brasília Belt, Central Brazil. Journal of South American Earth Sciences, 14(6):571-585.

Santos R.V., Alvarenga C.J.S., Babinski M., Ramos M.L.S., Cukrov A.N., Fonseca M.A., Sial A.N., Dardenne M.A. \& Noce C.M. 2004. Carbon isotopes of Mesoproterozoic-Neoproterozoic sequences from Southern São Francisco craton and Araçuaí Belt, Brazil: Paleographic implications. Journal of South American Earth Sciences, 18(1):27-39.

Santos R.V., Alvarenga C.J.S., Dardenne M.A., Sial A.N. \& Ferreira V.P. 2000. Carbon and oxygen isotope profiles across MesoNeoproterozoic limestones from central Brazil: Bambuí and Paranoá groups. Precambrian Research, 104(3-4):107-122.

Teixeira L.B., Martins M. \& Braun O.P.G. 1993. Evolução geológica da Bacia do São Francisco com base em sísmica de reflexão e métodos potenciais. In: Simpósio Sobre o Cráton do São Francisco, 2., 1993. Salvador. Anais... Salvador, Sociedade Brasileira de Geologia, p. 179-181. 